\title{
Activation of small molecules over praseodymium-doped ceria
}

\author{
Meiling Guo a , Xuebin Liu a , Angelo Amorelli b,* \\ a Energy Innovation Laboratory, BP (China) Dalian Office, Dalian 116023, Liaoning, China \\ ${ }^{\mathrm{b}}$ Group Research, BP International, Sunbury, TW16 7LN, United Kingdom
}

\section{A R T I C L E I N F}

\section{Article history:}

Accepted 4 April 2019

Published 5 November 2019

\section{Keywords:}

$\mathrm{CeO}_{2}$

Pr dopant

Oxygen vacancy

Degree of reduction

Propane dehydrogenation
Received 29 January 2019

\section{A B S T R A C T}

Praseodymium can modify the properties of ceria $\left(\mathrm{CeO}_{2}\right)$, changing the electronic structure, reducibility and catalytic behavior. Oxygen vacancies in the ceria-based samples can activate $\mathrm{C}-\mathrm{O}$ and $\mathrm{C}-\mathrm{H}$ bonds of small molecules such as $\mathrm{CO}_{2}$ and propane. Partially reduced $\mathrm{Pr} / \mathrm{CeO}_{2-x}$ can selectively activate $\mathrm{C}-\mathrm{H}$ of propane, giving a propylene selectivity of ca. $75 \%$ at a propane conversion of $5 \%$ to $10 \%$. Excess reduction of $\mathrm{Pr} / \mathrm{CeO}_{2-x}$ induces coking reactions during propane dehydrogenation, resulting in fast catalyst deactivation.

(C) 2019, Dalian Institute of Chemical Physics, Chinese Academy of Sciences. Published by Elsevier B.V. All rights reserved.

\section{Introduction}

$\mathrm{ZrO}_{2}$ abovementioned.

$\mathrm{CeO}_{2}$ is a reducible oxide that is widely applied as a support or promoter in catalytic materials because of its unique redox properties [4-10]. When used as a support, $\mathrm{CeO}_{2}$ is able to trap Pt atoms in an ionic form, enhancing the Pt dispersion and inhibiting Pt sintering in catalysts for the non-oxidative propane dehydrogenation $[11,12]$. As a promoter ( $<1 \mathrm{wt} \%), \mathrm{CeO}_{2}$ can tune the propane dehydrogenation performance and improve the stability of $\mathrm{PtSn} / \mathrm{Al}_{2} \mathrm{O}_{3}$ [13]. In many cases, $\mathrm{CeO}_{2}$ in combination with noble metals leads to superior catalytic performance. Knowledge on the role of $\mathrm{CeO}_{2}$ itself (without loading conventional hydrogenation/dehydrogenation metals) in $\mathrm{C}-\mathrm{H}$ and C-C bond activation of light alkanes is still limited.

Doping with metals of lower valence states is an effective way to induce the formation of oxygen vacancies in $\mathrm{CeO}_{2}$. Extensive studies have focused on $3 d$ transition metal $\left(\mathrm{Ni}^{2+}, \mathrm{Co}^{2+}\right.$, $\mathrm{Cr}^{3+}$, etc.)-doped $\mathrm{CeO}_{2}$ [14-16]. However, it is suggested that transition metal ions do not incorporate into the oxide lattices but instead phase segregate into transition metal oxide nano-

\footnotetext{
* Corresponding author. E-mail: angelo.amorelli@bp.com

DOI: S1872-2067(19)63369-3 | http://www.sciencedirect.com/science/journal/18722067 | Chin. J. Catal., Vol. 40, No. 11 , November 2019
} 
particles [17]. Such problems could be overcome in rare earth metal-doped $\mathrm{CeO}_{2}$, in which the rare earth ions can achieve full dissolution into the $\mathrm{CeO}_{2}$ lattice. Among the various rare earth elements used as dopants for ceria catalysts, praseodymium has received a significant interest over the last few years [18-21]. Pr species embedded into the ceria lattice promote the formation of oxygen vacancies and the mobility of negatively charged ions in the solid framework [18]. Moreover, our recent studies have shown that the oxygen vacancies induced by the Pr doping of $\mathrm{CeO}_{2}$ promotes the catalytic performance of the Prins condensation-hydrolysis of isobutene with formalin [22,23].

The aim of this work is to investigate the structures of defects, the reducibility of $\mathrm{Pr}$-doped $\mathrm{CeO}_{2}$, and its capability for the activation of small molecules ( $\mathrm{CO}_{2}$ and propane) in the absence of hydrogenation/dehydrogenation metals (e.g. Pt or $\mathrm{CrO}_{x}$ etc.). $\mathrm{Pr} / \mathrm{CeO}_{2}$ was prepared by a co-precipitation method and characterized by X-ray diffraction (XRD), UV-Vis absorption spectrophotometry, and Raman spectrometry. The reducibility of $\mathrm{Pr} / \mathrm{CeO}_{2}$ was investigated by temperature-programmed reduction (TPR) in hydrogen. The degree of reduction was further characterized by titration using $\mathrm{CO}_{2}$ as a probe molecule by the temperature-programmed surface reaction ( $\mathrm{CO}_{2}$-TPSR). $\mathrm{CO}_{2}$ reduction with hydrogen $\left(\mathrm{H}_{2} \& \mathrm{CO}_{2}\right.$-TPSR) was used as a probe reaction to investigate the influence of the degree of reduction on the catalytic performance. Finally, propane dehydrogenation was used as a model reaction to evaluate $\mathrm{C}-\mathrm{H}$ and $\mathrm{C}-\mathrm{C}$ activation by the oxygen vacancies. This work will help understand the inherent catalytic properties of ceria-based materials and explore the potential of oxygen vacancies in metal oxide catalysts for light hydrocarbon conversion.

\section{Experimental}

\subsection{Catalyst preparation}

Pr-doped $\mathrm{CeO}_{2}$ catalyst with a Ce/Pr molar ratio of 4:1 was prepared by a co-precipitation method [22]. $4 \mathrm{~g}$ of $\mathrm{Ce}\left(\mathrm{NO}_{3}\right)_{3} \cdot 6 \mathrm{H}_{2} \mathrm{O}$ and $1 \mathrm{~g}$ of $\operatorname{Pr}\left(\mathrm{NO}_{3}\right)_{3} \cdot 6 \mathrm{H}_{2} \mathrm{O}$ were dissolved in 100 $\mathrm{mL}$ of deionized water. The ammonium hydroxide solution was added drop-wise to the solution whilst stirring to maintain a $\mathrm{pH}$ of 11 and the solution was subsequently stirred for $2 \mathrm{~h}$. The mixture was filtered and dried at $120^{\circ} \mathrm{C}$ for $12 \mathrm{~h}$, and the recovered solid calcined at $550{ }^{\circ} \mathrm{C}$ under a flow of air $(50 \mathrm{~mL}$ $\mathrm{min}^{-1}$ ) for $4 \mathrm{~h}$ to obtain the final material. For comparison a $\mathrm{CeO}_{2}$ sample was also prepared without adding the Pr dopant.

\subsection{Catalyst characterization}

XRD patterns were collected on a PANalytical X'Pert powder diffractometer using $\mathrm{Cu} \mathrm{K}_{\alpha}$ radiation, operated at $40 \mathrm{kV}$ and 40 $\mathrm{mA}$. UV-Vis absorption spectra were recorded on a JASCO V650 UV-Vis spectrophotometer. Thermogravimetric analysis (TGA) measurements were carried out on a Netzsch TG-DTA apparatus (Netzsch, Germany). About $10 \mathrm{mg}$ sample was placed in an $\mathrm{Al}_{2} \mathrm{O}_{3}$ crucible and heated at a ramping rate of $10^{\circ} \mathrm{C} \mathrm{min}-1$ under an air flow of $20 \mathrm{~mL} \mathrm{~min}^{-1}$.
Visible Raman spectra were collected on the Renishaw micro-Raman spectrometer equipped with a CCD detector using the laser wavelengths of 785 and $532 \mathrm{~nm}$. UV Raman spectra were collected using a home-built spectrometer with a laser wavelength of $325 \mathrm{~nm}$ (Kimmon Co). All spectra were calibrated by placing the main Raman peak of monocrystalline Si at $520 \mathrm{~cm}^{-1}$. For most experiments, the laser power at the sample was kept below $1 \mathrm{~mW}$ to prevent burning effects.

For operando UV Raman experiments, a $30 \mathrm{mg}$ catalyst sample was loaded in an in-situ cell and purged with helium at $400{ }^{\circ} \mathrm{C}$ for $30 \mathrm{~min}$. Subsequently the feed gas (2 vol\% $\left.\mathrm{H}_{2}\right)$ was introduced with a flow rate of $25 \mathrm{~mL} \mathrm{~min}^{-1}$ at $400{ }^{\circ} \mathrm{C}$ and then ramped to the desired temperature under the flow of hydrogen. The catalyst sample was characterized on-line with the UV Raman spectrometer while the effluent was on-line analyzed using a Pfeiffer quadrupole mass spectrometer to monitor the profile of hydrogen and water as a function of time and temperature.

$\mathrm{H}_{2}$-TPR experiments were performed with a Quantachrome autosorb iQ. First, $50 \mathrm{mg}$ sample was loaded in a U-shaped quartz reactor and purged with helium to remove the adsorbed species at $500{ }^{\circ} \mathrm{C}$ for $30 \mathrm{~min}$ with a heating rate of $10^{\circ} \mathrm{C} \mathrm{min}-1$. After cooling to $40^{\circ} \mathrm{C}$, the purge gas was switched to a feed of 3 vol $\% \mathrm{H}_{2}$ in helium with a flow rate of $30 \mathrm{~mL} \mathrm{~min}^{-1}$. The $\mathrm{H}_{2}-\mathrm{TPR}$ experiment was carried out with a heating rate of $10^{\circ} \mathrm{C} \mathrm{min}-1$ up to the desired temperature. The effluent was monitored with a thermal conductivity detector (TCD) and a Pfeiffer quadrupole mass spectrometer. The amount of hydrogen consumed per catalyst mass was calculated according to the TCD signals. The integrated area translated to the amount of hydrogen consumption using calibrated curves of the hydrogen amount to the peak area.

The procedure for TPSR was similar to the $\mathrm{H}_{2}$-TPR but used the feeds described in Table 1 . The following mass to charge $(\mathrm{m} / \mathrm{z})$ signals were monitored: $44\left(\mathrm{CO}_{2}\right), 40(\mathrm{Ar}), 32\left(\mathrm{O}_{2}\right), 28$ (CO), 18 (water), 4 (He), 2 ( $\left.\mathrm{H}_{2}\right)$.

\subsection{Propane dehydrogenation test}

Propane dehydrogenation tests were carried out in a tubular quartz reactor with an inner diameter of $10 \mathrm{~mm}$ at $570{ }^{\circ} \mathrm{C}$ and atmospheric pressure. $200 \mathrm{mg}$ of catalyst (40-60 mesh) was diluted with $250 \mathrm{mg}$ of quartz sand. Prior to catalytic performance tests, the as-synthesized samples were pretreated with $\mathrm{Ar}$ at $550{ }^{\circ} \mathrm{C}$ for $1 \mathrm{~h}$ or $5 \mathrm{vol} \% \mathrm{H}_{2} / \mathrm{Ar}$ at $550(650)^{\circ} \mathrm{C}$ for 1 $\mathrm{h}$, corresponding to the propane performance testing over $\mathrm{Pr} / \mathrm{CeO}_{2}$ or the pre-reduced $\mathrm{Pr} / \mathrm{CeO}_{2-x}$ at $550(650){ }^{\circ} \mathrm{C}$, respectively. Then propane feed ( $4 \mathrm{vol} \%$ propane, 2 vol\% $\mathrm{N}_{2}$ in $\mathrm{He}$ )

Table 1

Feeds for the TPSR.

\begin{tabular}{ll}
\hline Experiment & Feed diluted in helium or argon \\
\hline $\mathrm{H}_{2}$-TPR & 3 vol\% $\mathrm{H}_{2}$ \\
$\mathrm{CO}_{2}$-TPSR & 2 vol\% $\mathrm{CO}_{2}$ \\
$\mathrm{H}_{2}$ \& $\mathrm{CO}_{2}$-TPSR & 2 vol $\% \mathrm{CO}_{2}$ and 2 vol $\% \mathrm{H}_{2}$ \\
$\begin{array}{l}\text { TPO (temperature-programmed } \\
\text { oxidation) }\end{array}$ & 3 vol $\% \mathrm{O}_{2}$ \\
\hline
\end{tabular}


was introduced through the catalyst bed at a total flow rate of $40 \mathrm{~mL} \mathrm{~min}^{-1}$. The effluent was analyzed on-line using an Agilent MicroGC 490. Nitrogen was used as an internal standard for the performance calculations. Hydrogen, nitrogen, methane, and $\mathrm{CO}$ were analyzed with a molecular sieve column and TCD. $\mathrm{CO}_{2}$, ethylene, and ethane were analyzed using a PoraPLOT U column and TCD. Propane and propylene were analyzed with an aluminum oxide column and TCD. The partial pressures of the unconverted feed and products were directly determined using calibrated micro-GC. The flow rates of the unconverted feed and collected products were calculated based on the internal standard, nitrogen. The conversion of propane was determined as the amount of reacted propane divided by the amount of propane at the reactor inlet. The carbon selectivity of each compound was calculated as the quantity of the product formed divided by the amount of converted propane. The fitted hydrogen was calculated according to the below two equations:

$$
\begin{aligned}
x \mathrm{C}_{3} \mathrm{H}_{8}+3 \mathrm{Pr} / \mathrm{CeO}_{2} & \rightarrow 3 x \mathrm{CO}+4 x \mathrm{H}_{2}+3 \mathrm{Pr} / \mathrm{CeO}_{2-x} \\
\mathrm{C}_{3} \mathrm{H}_{8} & \rightarrow \mathrm{C}_{3} \mathrm{H}_{6}+\mathrm{H}_{2}
\end{aligned}
$$

Partial pressure of fitted $\mathrm{H}_{2}=4 / 3 \times$ Partial pressure of $\mathrm{CO}+$ Partial pressure of propylene

\section{Results and discussion}

\subsection{Characterizations (XRD, UV-Vis Absorption spectroscopy, and Raman spectroscopy)}

Fig. 1a shows the XRD patterns of as-synthesized $\mathrm{CeO}_{2}$ and $\mathrm{Pr} / \mathrm{CeO}_{2}$. The observed peaks in the XRD patterns are well indexed and consistent with the reference data of $\mathrm{CeO}_{2}$, which indicates the single phase cubic fluorite structure. The optical properties of $\mathrm{CeO}_{2}$ and $\mathrm{Pr} / \mathrm{CeO}_{2}$ were characterized by UV-Vis absorption spectroscopy shown in Fig. 1b. The spectrum of $\mathrm{CeO}_{2}$ shows a strong absorption band below $400 \mathrm{~nm}$, which originates from the $\mathrm{O}^{2-}$ to $\mathrm{Ce}^{3+} /{ }^{4+}$ charge transfer transition [24]. $\mathrm{Pr} / \mathrm{CeO}_{2}$ shows a high intensity visible light absorption in 400-650 nm, which has been assigned to the charge transfer transition from $\mathrm{O}^{2-}$ to $\mathrm{Pr}^{3+} /{ }^{4+}$ [24-27].

Raman spectroscopy is a useful technique in the characterization of defects of the oxide samples. The defects of $\mathrm{CeO}_{2}$ were studied by Raman spectroscopy using 785, 532, and $325 \mathrm{~nm}$

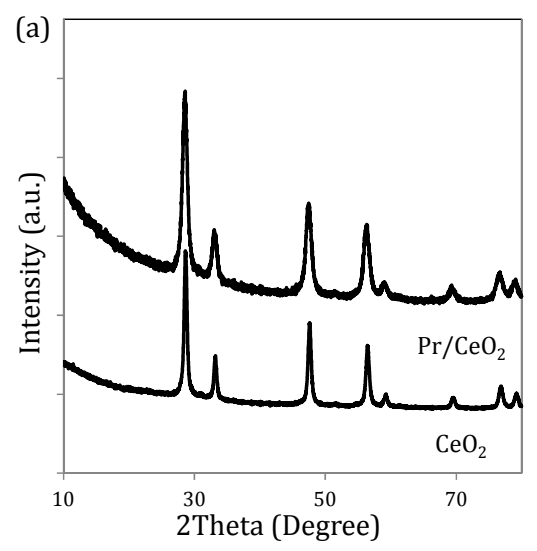

excitation laser lines (Fig. 2a). The spectra excited with the 785 and $532 \mathrm{~nm}$ laser lines both have a single band at $460 \mathrm{~cm}^{-1}$. The spectrum excited with the $325 \mathrm{~nm}$ laser line shows a band at $460 \mathrm{~cm}^{-1}$ and another band centered at $590 \mathrm{~cm}^{-1}$. The band at $590 \mathrm{~cm}^{-1}$ can be explained by a resonance Raman effect, since $\mathrm{CeO}_{2}$ strongly absorbs in the $\mathrm{UV}$ region around $325 \mathrm{~nm}$ as shown in Fig 1b [28].

The bands at 460 and $590 \mathrm{~cm}^{-1}$ are related to the Raman-active vibrational mode $\left(\mathrm{F}_{2 \mathrm{~g}}\right)$ of fluorite-type structure and the defects of $\mathrm{CeO}_{2}$, respectively $[27,29]$. The $\mathrm{F}_{2 \mathrm{~g}}$ band is the symmetrical stretching vibration of the oxygen atoms around cerium ions. The defect species characterized by the band at $590 \mathrm{~cm}^{-1}$ was observed under ambient conditions and its concentration may be low as it cannot be observed without the resonance enhancement effect.

To validate the structure of the defect characterized by the band at $590 \mathrm{~cm}^{-1}, \mathrm{CeO}_{2}$ was studied by operando UV Raman spectroscopy (Fig. 2b). Compared to the spectrum obtained under ambient condition shown in Fig 2a, there are no changes of the band at $590 \mathrm{~cm}^{-1}$ after helium and hydrogen treatments at $400{ }^{\circ} \mathrm{C}$. This band shifts to $570 \mathrm{~cm}^{-1}$ upon the hydrogen treatment at elevated temperature such as 550 and $650{ }^{\circ} \mathrm{C}$ shown in Fig. 2b. The shift of band occurs upon on-line hydrogen treatment and should be related to the oxygen vacancy produced by the hydrogen treatment [30]. The consumption of the hydrogen and formation of water were observed by an on-line mass spectrometer during the operando Raman test in Fig. S1, confirming the formation of oxygen vacancies induced by the hydrogen reduction of $\mathrm{CeO}_{2}$.

The $\mathrm{Pr} / \mathrm{CeO}_{2}$ shows the different optical properties with strong absorbance in the visible region as shown in Fig. 1b. The impact of the Pr dopant on the structure and amount of the defects was investigated by Raman spectroscopy as shown in Fig. 3a. The spectrum of $\mathrm{Pr} / \mathrm{CeO}_{2}$ excited with $785 \mathrm{~nm}$ laser line shows a vibrational band of fluorite-type structure at $455 \mathrm{~cm}^{-1}$ and a weak peak centered at $570 \mathrm{~cm}^{-1}$. The spectrum collected with $532 \mathrm{~nm}$ excitation laser line is different to the spectrum collected with $785 \mathrm{~nm}$ excitation laser line. The peak area ratios of the bands at 570 and $455 \mathrm{~cm}^{-1}$ are 0.2 and 3.3 for the spectra collected with the excitation laser lines of 785 and $532 \mathrm{~nm}$, respectively. This difference can be explained by a resonance

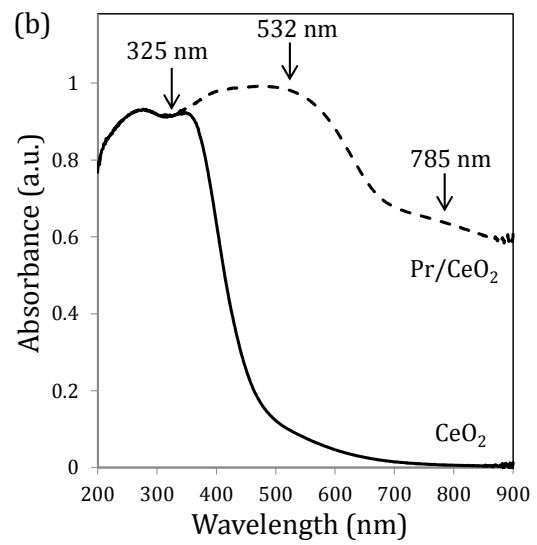

Fig. 1. XRD patterns (a) and UV-Vis absorption spectra (b) of $\mathrm{CeO}_{2}$ and $\mathrm{Pr} / \mathrm{CeO}_{2}$. 

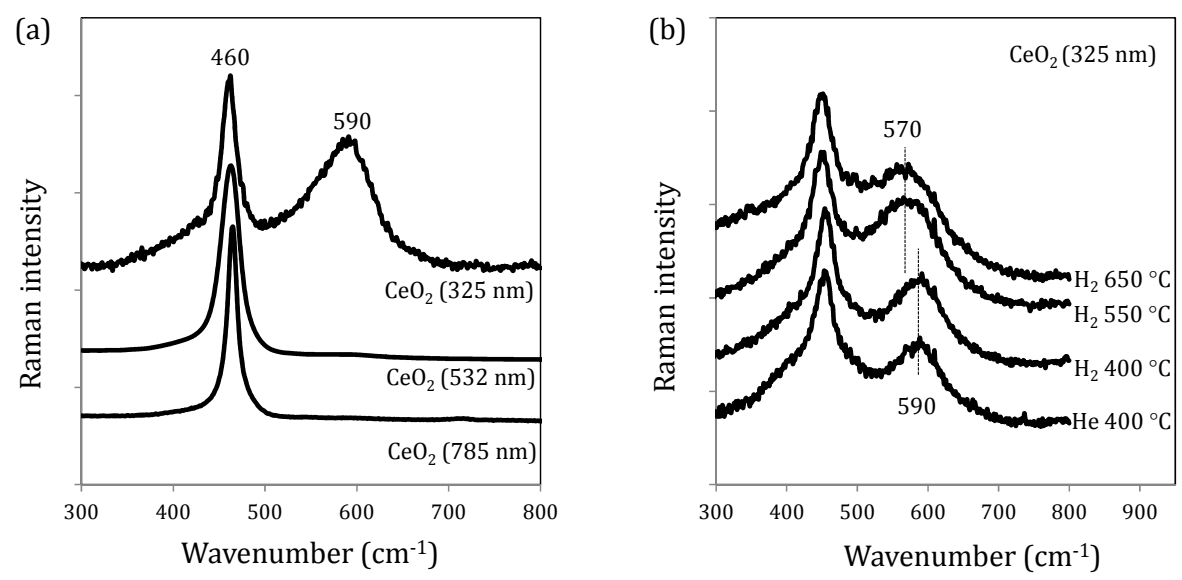

Fig. 2. Raman spectra of $\mathrm{CeO}_{2}$ excited with 785, 532, and $325 \mathrm{~nm}$ laser lines (a) and operando UV Raman spectra of $\mathrm{CeO}_{2}$ (b).
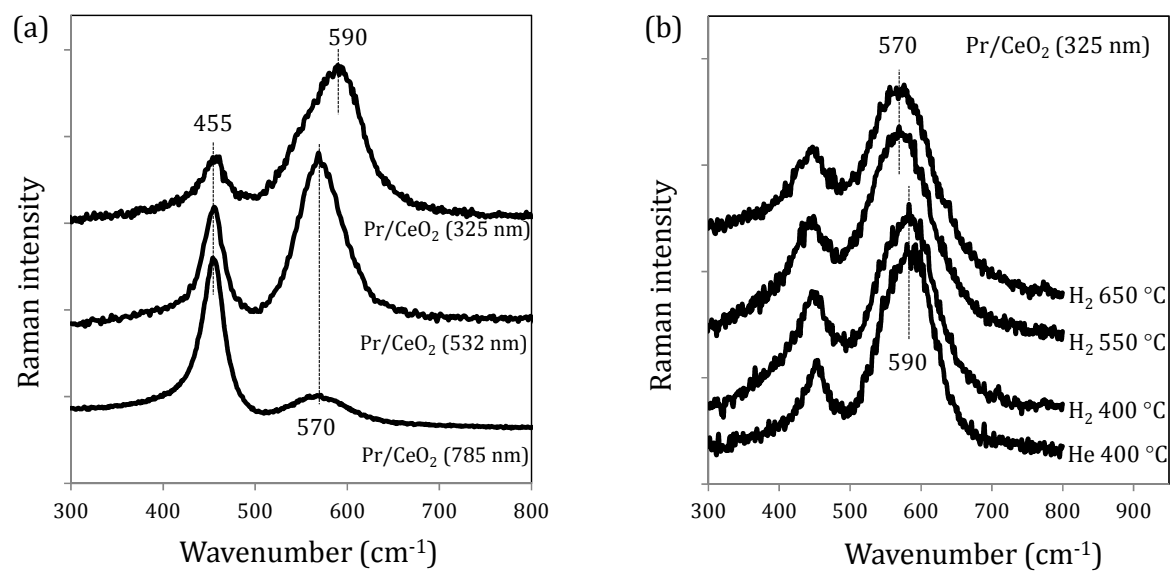

Fig. 3. Raman spectra of $\mathrm{Pr} / \mathrm{CeO}_{2}$ excited with 785, 532, and $325 \mathrm{~nm}$ laser lines (a) and operando UV Raman spectra of $\mathrm{Pr} / \mathrm{CeO}$ (b).

Raman effect, since $\mathrm{Pr} / \mathrm{CeO}_{2}$ strongly absorbs in the visible region around $532 \mathrm{~nm}$ as marked in Fig 1b. Compared with the visible Raman results, the $325 \mathrm{~nm}$ excited UV Raman shows a band centered at $590 \mathrm{~cm}^{-1}$ rather than $570 \mathrm{~cm}^{-1}$ and the peak area ratio of the bands at 590 and $460 \mathrm{~cm}^{-1}$ is further increased to 6.7 .

For $\mathrm{Pr} / \mathrm{CeO}_{2}$, the band around $570-590 \mathrm{~cm}^{-1}$ might be related to the intrinsic defects of $\mathrm{CeO}_{2}\left(590 \mathrm{~cm}^{-1}\right)$, the $\mathrm{Pr}^{3+}$ induced oxygen vacancy $\left(570 \mathrm{~cm}^{-1}\right)$ and the vibration of the $\mathrm{Pr}-0$ species around $550 \mathrm{~cm}^{-1}$ [31]. Due to complexities of the band and the resonance Raman effect (resulting in different peak area ratios between the band at 570-590 and $455 \mathrm{~cm}^{-1}$ for different laser lines), the amount of the defects cannot be directly calculated by Raman results. However, the shift of the band of fluorite-type structure from 460 to $455 \mathrm{~cm}^{-1}$ confirms that the Pr dopant changes the local structure of the sample as shown in Fig. S2.

To validate the structure and the evolution of defects in $\mathrm{Pr} / \mathrm{CeO}_{2}$, an operando UV Raman test was performed and the results are shown in Fig. 3b. The band at $590 \mathrm{~cm}^{-1}$ shifts to 570 $\mathrm{cm}^{-1}$ upon hydrogen treatment at elevated temperature such as 550 and $650{ }^{\circ} \mathrm{C}$. Combined with the on-line mass spectrometer results, this suggests that the Raman band shift is related to the formation of oxygen vacancies induced by hydrogen treatment. This band shift is similar to the above $\mathrm{CeO}_{2}$ test results shown in Fig. 2b.

\subsection{Temperature programmed reactions $\left(\mathrm{H}_{2}-\mathrm{TPR}, \mathrm{CO}_{2}-\mathrm{TPSR}\right.$, and $\mathrm{H}_{2} \& \mathrm{CO}_{2}$-TPSR)}

The reducibility of $\mathrm{CeO}_{2}$ and $\mathrm{Pr} / \mathrm{CeO}_{2}$ was investigated by temperature-programmed reactions. The $\mathrm{H}_{2}$-TPR profiles of the $\mathrm{CeO}_{2}$ and $\mathrm{Pr} / \mathrm{CeO}_{2}$ samples are shown in Fig. $4 \mathrm{a}$ and 4 b, respectively, and the characteristic data derived from these profiles are listed in Table 2. For $\mathrm{CeO}_{2}$, two reduction zones were observed. The low-temperature region $\left(350-630^{\circ} \mathrm{C}\right)$ corresponds to surface reduction while the high-temperature region $\quad>630$ ${ }^{\circ} \mathrm{C}$ ) is assigned to bulk reduction in agreement with previous publications [8,32]. The hydrogen consumption of $\mathrm{CeO}_{2}$ drops to zero at $630{ }^{\circ} \mathrm{C}$, suggesting that this temperature is the boundary temperature for the surface and bulk reduction under the testing condition. The surface reduction of $\mathrm{CeO}_{2}$ can be well deconvoluted into the peaks of $\alpha$ and $\beta$ with the peak area ratio of 1:1. The surface and overall hydrogen consumptions of $\mathrm{CeO}_{2}$ are 0.28 and $0.38 \mathrm{mmol} \mathrm{g}^{-1}$, respectively. The overall hydrogen consumption amount is similar to the previously re- 

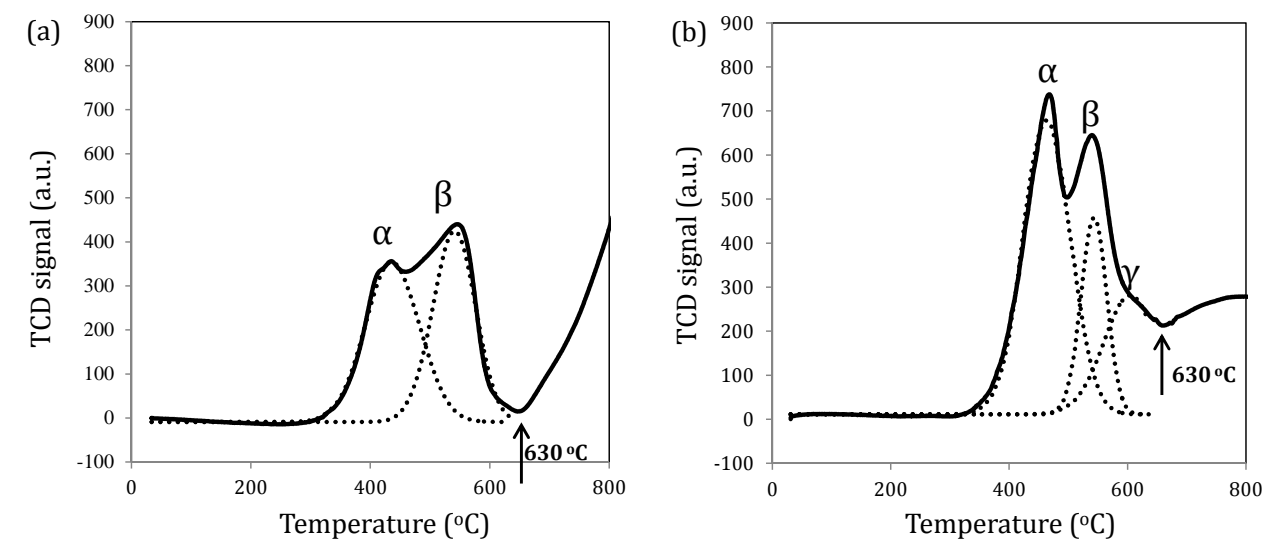

Fig. 4. $\mathrm{H}_{2}$-TPR TCD signals of $\mathrm{CeO}_{2}$ (a) and $\mathrm{Pr} / \mathrm{CeO}_{2}$ (b).

Table 2

$\mathrm{H}_{2}$-TPR quantitative analysis results for $\mathrm{CeO}_{2}$ and $\mathrm{Pr} / \mathrm{CeO}_{2}$.

\begin{tabular}{|c|c|c|c|c|c|c|}
\hline \multirow{3}{*}{ Sample } & \multicolumn{5}{|c|}{$\mathrm{H}_{2}$ consumption $\left(\mathrm{mmol} \mathrm{g}^{-1}\right)$} & \multirow{3}{*}{$x$ after reduction $(\mathrm{Pr}) \mathrm{CeO}_{2-x}$} \\
\hline & \multicolumn{3}{|c|}{ Surface $\left(350-630^{\circ} \mathrm{C}\right)$} & \multirow{2}{*}{ Bulk $\left(630-800^{\circ} \mathrm{C}\right)$} & \multirow{2}{*}{ Overall reduction $\left(350-800^{\circ} \mathrm{C}\right)$} & \\
\hline & Peak $\alpha$ & Peak $\beta$ & Peak $\gamma$ & & & \\
\hline$\overline{\mathrm{CeO}_{2}}$ & 0.14 & 0.14 & - & 0.10 & 0.38 & 0.065 \\
\hline $\mathrm{Pr} / \mathrm{CeO}_{2}$ & 0.27 & 0.1 & 0.13 & 0.19 & 0.69 & 0.118 \\
\hline
\end{tabular}

ported result of $0.34 \mathrm{mmol} \mathrm{g}^{-1}$ [33].

The respective surface and overall hydrogen consumptions of $\mathrm{Pr} / \mathrm{CeO}_{2}$ are 0.5 and $0.69 \mathrm{mmol} \mathrm{g}^{-1}$ as listed in Table 2. The $\mathrm{Pr}$ dopant not only increases the amount of hydrogen consumption but also tunes the material's reduction characteristics: (i) the peak area ratio of $\alpha$ and $\beta$ increases from 1 to 2.7; (ii) a new type of surface reduction peak $\gamma$ is formed; (iii) surface and bulk oxygen reduction cannot be distinguished clearly. The Pr-doped material still consumes hydrogen at $630{ }^{\circ} \mathrm{C}$, which is different to the $\mathrm{CeO}_{2}$.

$\mathrm{H}_{2}$-TPR was also monitored using a mass spectrometer, allowing the observation of hydrogen consumption and water formation. For Pr/ $\mathrm{CeO}_{2}$ in Fig. 5a, the hydrogen starts decreas- ing as the temperature reaches ca. $350{ }^{\circ} \mathrm{C}$ while the water signal is observed at the same time. Maxima in the amount of hydrogen consumed are centered at 480 and $570{ }^{\circ} \mathrm{C}$, coinciding with maxima in the amount of water produced. The mass spectra confirm that $\mathrm{Pr} / \mathrm{CeO}_{2}$ is reduced by $\mathrm{H}_{2}$ producing water. After $\mathrm{H}_{2}$ reduction, $\mathrm{Pr} / \mathrm{CeO}_{2}$ is in its reduced state, i.e. $\mathrm{Pr} / \mathrm{CeO}_{2-x}$, where $x$ indicates the amount of oxygen vacancies and its value is listed in Table 2 .

$\mathrm{CO}_{2}$ was used as a probe molecule to titrate the degree of reduction generated by the hydrogen treatment as a function of temperature. Before $\mathrm{CO}_{2}$-TPSR, the as-synthesized $\mathrm{Pr} / \mathrm{CeO}_{2}$ was pre-reduced in a flow of hydrogen at $450,550,650$ or $700{ }^{\circ} \mathrm{C}$ for $30 \mathrm{~min}$. Then $\mathrm{CO}_{2}$-TPSR was carried out in a flow of $\mathrm{CO}_{2}$
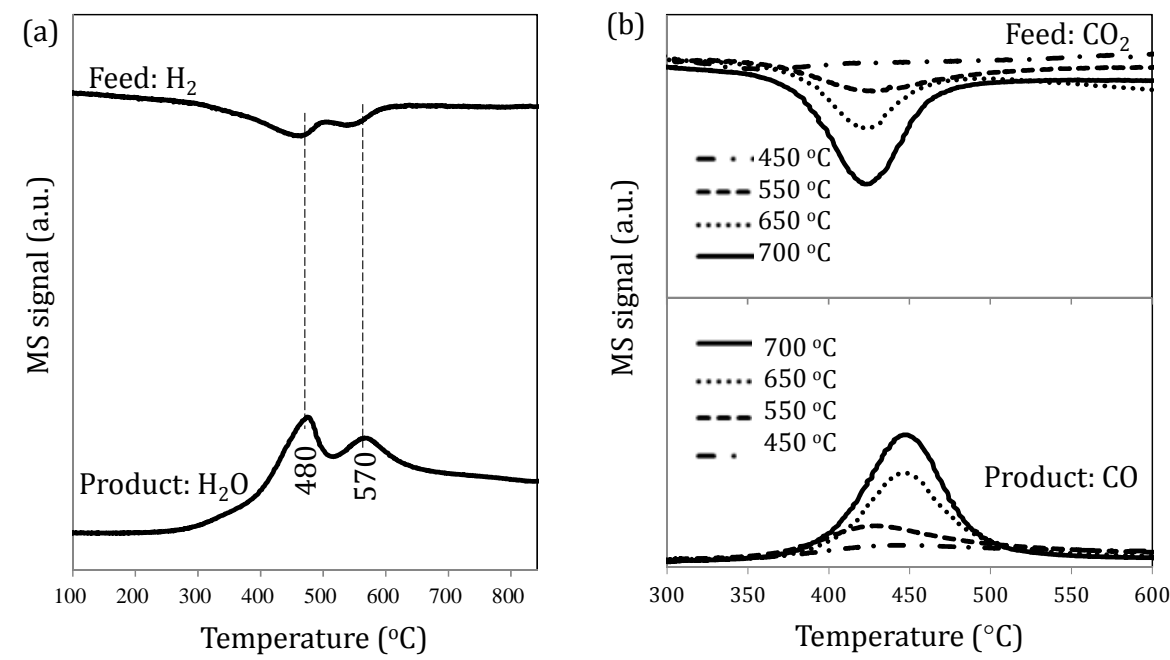

Fig. 5. $\mathrm{H}_{2}$-TPR profiles of $\mathrm{Pr} / \mathrm{CeO}_{2}$ (mass spectrometer signal) (a) and $\mathrm{CO}_{2}$-TPSR over the pre-reduced Pr/CeO ${ }_{2-x}$ as a function of pre-reduction temperature (b). 
from 300 to $600{ }^{\circ} \mathrm{C}$ with a heating rate of $10{ }^{\circ} \mathrm{C} \mathrm{min}-1$. As shown in Fig. $5 b$, over the $\mathrm{Pr} / \mathrm{CeO}_{2-x}$ pre-reduced at $700{ }^{\circ} \mathrm{C}$, the $\mathrm{CO}_{2}$ signal starts decreasing as the temperature reaches $400{ }^{\circ} \mathrm{C}$ and CO production is observed at the same time. This result suggests that $\mathrm{CO}_{2}$ can dissociate on oxygen vacancies releasing $\mathrm{CO}$, while the catalyst reverts from a reduced state to the initial oxidized state. The amount of $\mathrm{CO}$ relates to the degree of reduction and is lower with lower hydrogen pre-reduction temperatures. It is interesting to note that the pre-reduced sample at $450{ }^{\circ} \mathrm{C}$ shows little activity for the $\mathrm{CO}_{2}$ reduction.

$\mathrm{CO}_{2}$ reduction with hydrogen $\left(\mathrm{H}_{2} \& \mathrm{CO}_{2}\right.$-TPSR) was used as a probe reaction to validate the influence of the degree of reduction on the reaction performance. As shown in Fig. 6a, the initial surface reduction of $\mathrm{Pr} / \mathrm{CeO}_{2}$ in a $\mathrm{H}_{2} \& \mathrm{CO}_{2}$-TPSR experiment is quite similar to that observed in the $\mathrm{H}_{2}$-TPR experiment (Fig. 4b). Both show a starting reduction temperature around $350{ }^{\circ} \mathrm{C}$ and a peak of hydrogen consumption around $480{ }^{\circ} \mathrm{C}$. In addition, there is no $\mathrm{CO}_{2}$ consumption and $\mathrm{CO}$ formation below $480{ }^{\circ} \mathrm{C}$. This indicates that oxygen vacancies are generated at an early stage, corresponding to a low degree of reduction, and do not interact with $\mathrm{CO}_{2}$ at all. This result is similar to that observed in the $\mathrm{CO}_{2}$-TPSR experiment for the material pre-reduced at $450{ }^{\circ} \mathrm{C}$ in Fig. $5 \mathrm{c}$. It is interesting to observe that $\mathrm{CO}_{2}$ consumption occurs between 480 and $520{ }^{\circ} \mathrm{C}$ but without $\mathrm{CO}$ generation. It seems that oxygen vacancies are generated in this stage, corresponding to low-level degree of reduction, interact with $\mathrm{CO}_{2}$ but are unable to decompose $\mathrm{CO}_{2}$ into $\mathrm{CO}$. Further consumption of both $\mathrm{H}_{2}$ and $\mathrm{CO}_{2}$ was observed above $520^{\circ} \mathrm{C}$ along with the formation of water and CO. Obviously, oxygen vacancies generated at this stage, corresponding to a higher degree of reduction of $\mathrm{Pr} / \mathrm{CeO}_{2}$, can convert $\mathrm{CO}_{2}$ into CO.

The $\mathrm{CO}_{2}$ reduction to $\mathrm{CO}$ shown in Fig. 6a happens at $520^{\circ} \mathrm{C}$, much higher than the $400{ }^{\circ} \mathrm{C}$ in the $\mathrm{CO}_{2}$-TPSR over pre-reduced $\mathrm{Pr} / \mathrm{CeO}_{2-\mathrm{x}}$ (Fig. 5c). To address this, a $\mathrm{H}_{2} \& \mathrm{CO}_{2}$-TPSR experiment was performed over the hydrogen pre-reduced $\mathrm{Pr} / \mathrm{CeO} 2-x$ and the result is shown in Fig. 6b. As expected, $\mathrm{CO}_{2}$ was converted to $\mathrm{CO}$ over $\mathrm{Pr} / \mathrm{CeO}_{2-x}$ starting at $400{ }^{\circ} \mathrm{C}$ instead of $520^{\circ} \mathrm{C}$, indicating that the activity of oxygen vacancies generated relates to the material's degree of reduction. As shown in Fig. 6c and Fig. S3, the profiles of $\mathrm{CeO}_{2}$ are similar to that of $\mathrm{Pr} / \mathrm{CeO}_{2}$, and the difference is the lower amount of water in the region of $350-520^{\circ} \mathrm{C}$, in agreement with the $\mathrm{H}_{2}$-TPR results in Fig. 4.

As discussed above, $\mathrm{H}_{2} \& \mathrm{CO}_{2}$-TPSR results suggest that the ceria catalyst is reduced by $\mathrm{H}_{2}$ generating oxygen vacancies. Subsequently $\mathrm{CO}_{2}$ can be dissociated on the oxygen vacancies releasing $\mathrm{CO}$, while the catalyst changes back from the reduced state to the initial oxidized state. The catalyst cycle between the oxidized and reduced state initiates the $\mathrm{CO}_{2}$ reduction with hydrogen so that the overall reaction is reverse water gas shift.

\subsection{Catalytic performance (propane dehydrogenation)}

Propane activation reaction was used as a model reaction to investigate the influence of the degree of reduction and Pr dopant on the catalytic performance. This reaction was explored at a constant temperature of $570{ }^{\circ} \mathrm{C}$. The performance results of $\mathrm{Pr} / \mathrm{CeO}_{2}$ are summarized in Fig. 7 and Table 3. The sum of products carbon selectivities is the carbon molar ratio between the collected products and converted propane and its decrease indicates an obvious carbon loss in the later stage of the reaction, which should be in the form of coking. TGA and TPO analysis of the used catalyst confirms a carbon deposit about $3 \mathrm{wt} \%$ of the catalyst weight in Fig. S4. The reaction process can be divided into a relative stable stage and a fast coking stage. As shown in Fig. 7 and Table 3, the stable stage exhibits the following trends: (i) the initial activity is low and the activity gradually increases with time on stream (TOS); (ii) propylene is the main product and its selectivity increases quickly with time and then stabilizes at ca. 75\%; (iii) CO selectivity increases first and then stabilizes at ca. $15 \%$; (iv) $\mathrm{CO}_{2}$ is only detected at the initial time on steam. The formation of $\mathrm{CO}$ and $\mathrm{CO}_{2}$ implies that $\mathrm{Pr} / \mathrm{CeO}_{2}$ is reduced by propane in the early stage of the reaction. The material's degree of reduction keeps increasing, corresponding to more oxygen vacancies on the catalyst. The oxygen vacancies seem selective for the activation of the $\mathrm{C}-\mathrm{H}$ rather than $\mathrm{C}-\mathrm{C}$ bonds of propane, giving much higher propylene and lower ethylene yields. The product distribution suggests that the major reactions over $\mathrm{Pr} / \mathrm{CeO}_{2}$ are catalyst reduction and dehydrogenation of propane presented by the following equations:

$$
\begin{aligned}
x \mathrm{C}_{3} \mathrm{H}_{8}+3 \mathrm{Pr} / \mathrm{CeO}_{2} & \rightarrow 3 x \mathrm{CO}+4 x \mathrm{H}_{2}+3 \mathrm{Pr} / \mathrm{CeO}_{2-x} \\
\mathrm{C}_{3} \mathrm{H}_{8} & \rightarrow \mathrm{C}_{3} \mathrm{H}_{6}+\mathrm{H}_{2}
\end{aligned}
$$

The hydrogen partial pressure was fitted based on the CO
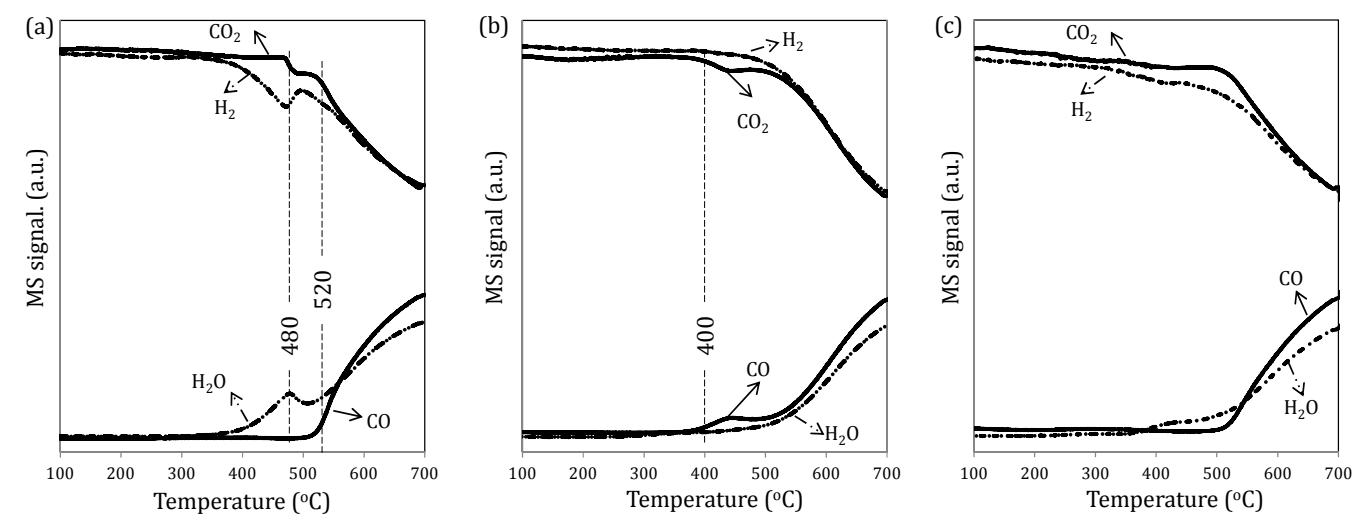

Fig. 6. $\mathrm{H}_{2}$ \& $\mathrm{CO}_{2}$ co-feed experiments for $\mathrm{Pr} / \mathrm{CeO}_{2}$ (a), $600{ }^{\circ} \mathrm{C}$ hydrogen pre-reduced $\mathrm{Pr} / \mathrm{CeO}_{2-x}$ (b), and $\mathrm{CeO}_{2}$ (c). 

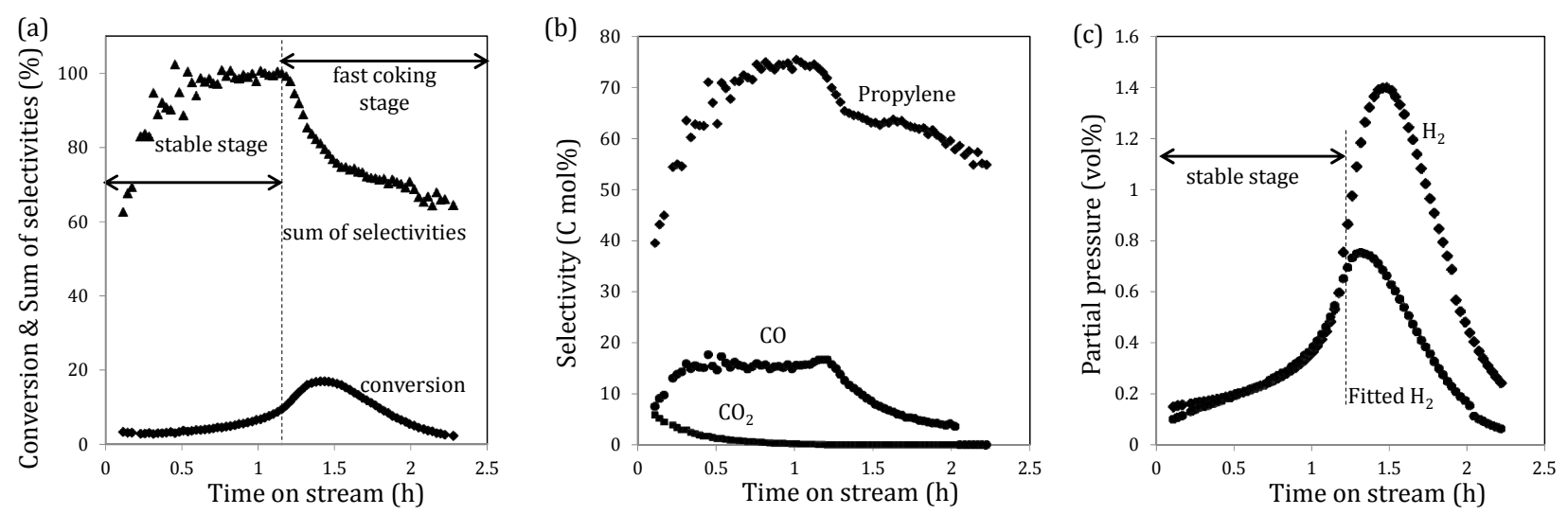

Fig. 7. Conversion and the sum of selectivities (a), main product selectivity (b), and collected hydrogen and fitted hydrogen (c) as a function of time on stream for $\mathrm{Pr} / \mathrm{CeO}_{2}$.

and propylene partial pressure using the two equations above. The collected hydrogen and fitted hydrogen are in good agreement for the relative stable performance stage shown in Fig. 7c.

The fast coking stage exhibits the following trends: (i) the conversion of propane does not start to drop until significant carbon deposits have built up; (ii) side reaction $\mathrm{C}_{3} \mathrm{H}_{8} \rightarrow 3 \mathrm{C}$ (coke) $+4 \mathrm{H}_{2}$ occurs in the coking stage, which is confirmed by the carbon loss along with the big difference between the collected and fitted hydrogen partial pressure, which indicates the boundary of relative stable stage and fast coking stage; (iii) propylene selectivity is still around $50 \%$.

The degree of reduction and activity of the oxygen vacancies of $\mathrm{Pr} / \mathrm{CeO}_{2}$ can be tuned by the hydrogen reduction temperature as shown in Fig. 5b. The sample pre-reduced by hydrogen at $650{ }^{\circ} \mathrm{C}$ has higher degree of reduction than the sample pre-reduction by hydrogen at $550{ }^{\circ} \mathrm{C}$. The performance data of the $\mathrm{Pr} / \mathrm{CeO}_{2-x}$ formed by pre-reduction in hydrogen at 550 and $650{ }^{\circ} \mathrm{C}$ are given in Fig. 8 with the reference of $\mathrm{Pr} / \mathrm{CeO}_{2}$. The $\mathrm{Pr} / \mathrm{CeO}_{2-x}$ produced by pre-reduced in hydrogen at $650{ }^{\circ} \mathrm{C}$ exhibits higher initial activity and propylene selectivity. This result is in agreement with the activity observed in the $\mathrm{CO}_{2}$ reduction experiments (Fig. 5b) and further confirms that the oxygen vacancies have the ability to activate the $\mathrm{C}-\mathrm{H}$ bonds of propane producing propylene as shown in Fig. 8a and 8b. The $\mathrm{CO}_{2}$ formation by full oxidation of propane is greatly or fully eliminated for $\mathrm{Pr} / \mathrm{CeO}_{2-x}$ formed by pre-reduction by hydrogen at 550 and $650{ }^{\circ} \mathrm{C}$ as shown in Fig. 8c. The CO formation is also obviously lower for the hydrogen pre-reduced samples as shown in Fig. 8d.

The performance of propane conversion over $\mathrm{CeO}_{2}$ is summarized in Fig. S5 and Table S1. The performance profiles over $\mathrm{CeO}_{2}$ are similar to that of $\mathrm{Pr} / \mathrm{CeO}_{2}$, but the selectivities for partial oxidation product $\mathrm{CO}$, selective dehydrogenation product propylene, and the coke formation are different, as shown in Fig. 9. The typical performance data of $\mathrm{CeO}_{2}$ and $\mathrm{Pr} / \mathrm{CeO}_{2}$ are compared at similar propane conversions (Fig. 9a), aiming to investigate the impact of the Pr dopant on the product selectivities. For the relatively stable performance stage (entries 1-5), $\mathrm{Pr} / \mathrm{CeO}_{2}$ gives higher selectivity to propylene, lower selectivity to $\mathrm{CO}$, and lower selectivity to coke as shown in Fig. 9b, 9c and 9d, respectively. For the fast coking stage (entries 6-8), the product selectivities of the two samples are similar, exhibiting much higher coke selectivity around $27 \%-31 \%$ due to the side reaction of $\mathrm{C}_{3} \mathrm{H}_{8} \rightarrow 3 \mathrm{C}$ (coke) $+4 \mathrm{H}_{2}$.

Based on the above results, the oxygen vacancies seem responsible for the selective activation of the $\mathrm{C}-\mathrm{H}$ bonds of propane resulting in propylene formation. During the early stable performance stage the activity is proportional to the amount of oxygen vacancies. Increases in the amount of oxygen vacancies (high degree of reduction) induce side reactions like the decomposition of propane to coke (carbon deposits) and hydrogen. The carbon deposition causes the deactivation of the catalyst. The Pr dopant suppresses the formation of byproducts of $\mathrm{CO}$ and coke in the initial stable stage, giving higher propylene

Table 3

The typical propane activation reaction performance data for $\mathrm{Pr} / \mathrm{CeO}_{2}$.

\begin{tabular}{|c|c|c|c|c|c|c|c|c|c|c|}
\hline \multirow{2}{*}{$\begin{array}{l}\text { Entry } \\
\text { No }\end{array}$} & \multirow{2}{*}{$\begin{array}{l}\text { TOS } \\
\text { (h) }\end{array}$} & \multirow{2}{*}{$\begin{array}{c}\text { Conversion } \\
(\%)\end{array}$} & \multicolumn{7}{|c|}{ Product carbon selectivity (C mol\%) } & \multirow{2}{*}{$\begin{array}{c}\text { Carbon balance } \\
(\%)\end{array}$} \\
\hline & & & Propylene & Ethylene & Ethane $^{*}$ & Methane & $\mathrm{CO}$ & $\mathrm{CO}_{2}{ }^{*}$ & Sum & \\
\hline$\overline{1}$ & 0.82 & 5.0 & 75.0 & 3.2 & 0 & 6.5 & 15.7 & 0.4 & 100.8 & 100.0 \\
\hline 2 & 0.93 & 6.0 & 74.4 & 2.6 & 0 & 6.8 & 15.1 & 0.2 & 99.1 & 99.9 \\
\hline 3 & 1.04 & 7.3 & 75.0 & 2.0 & 0 & 7.3 & 15.6 & 0.1 & 100.0 & 100.0 \\
\hline 4 & 1.10 & 8.3 & 74.2 & 1.8 & 0 & 7.7 & 15.7 & 0.1 & 99.5 & 100.0 \\
\hline 5 & 1.15 & 9.6 & 73.8 & 1.5 & 0 & 8.1 & 16.6 & 0.1 & 100.1 & 100.0 \\
\hline 6 & 1.82 & 9.1 & 62.1 & 1.2 & 1.3 & 2.4 & 4.6 & 0 & 71.6 & 97.4 \\
\hline 7 & 1.88 & 7.8 & 61.7 & 1.5 & 1.5 & 2.5 & 4.2 & 0 & 71.4 & 97.8 \\
\hline 8 & 1.96 & 6.2 & 58.9 & 1.9 & 1.9 & 2.8 & 3.8 & 0 & 69.3 & 98.1 \\
\hline
\end{tabular}

${ }^{*}$ Concentrations of the ethane (entries 1-6) and $\mathrm{CO}_{2}$ (entry 6-9) were below the GC limit of detection. 

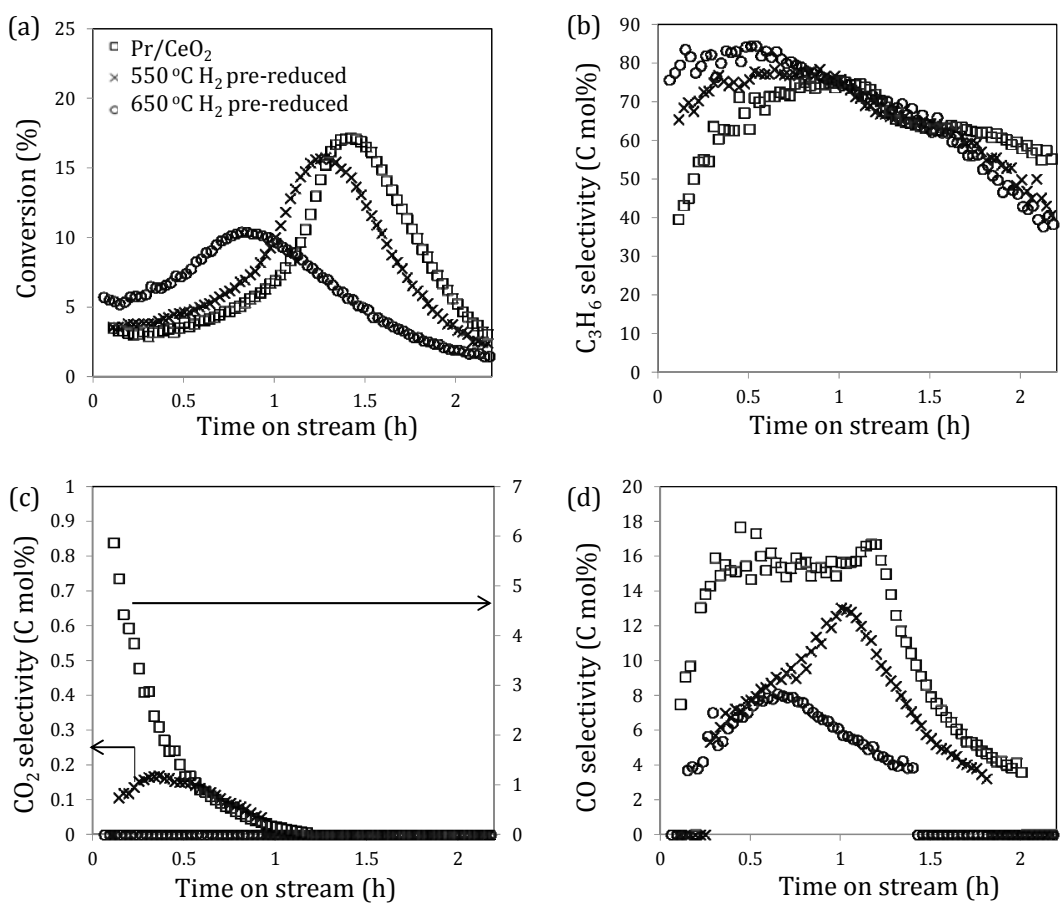

Fig. 8. Conversion (a), propylene selectivity (b), $\mathrm{CO}_{2}$ selectivity (c), and $\mathrm{CO}$ selectivity (d) as a function of time on stream for Pr/CeO ${ }_{2-x}$ formed by the hydrogen pre-reduction at 550 and $650^{\circ} \mathrm{C}$ with comparison to the results for $\mathrm{Pr} / \mathrm{CeO}_{2}$.
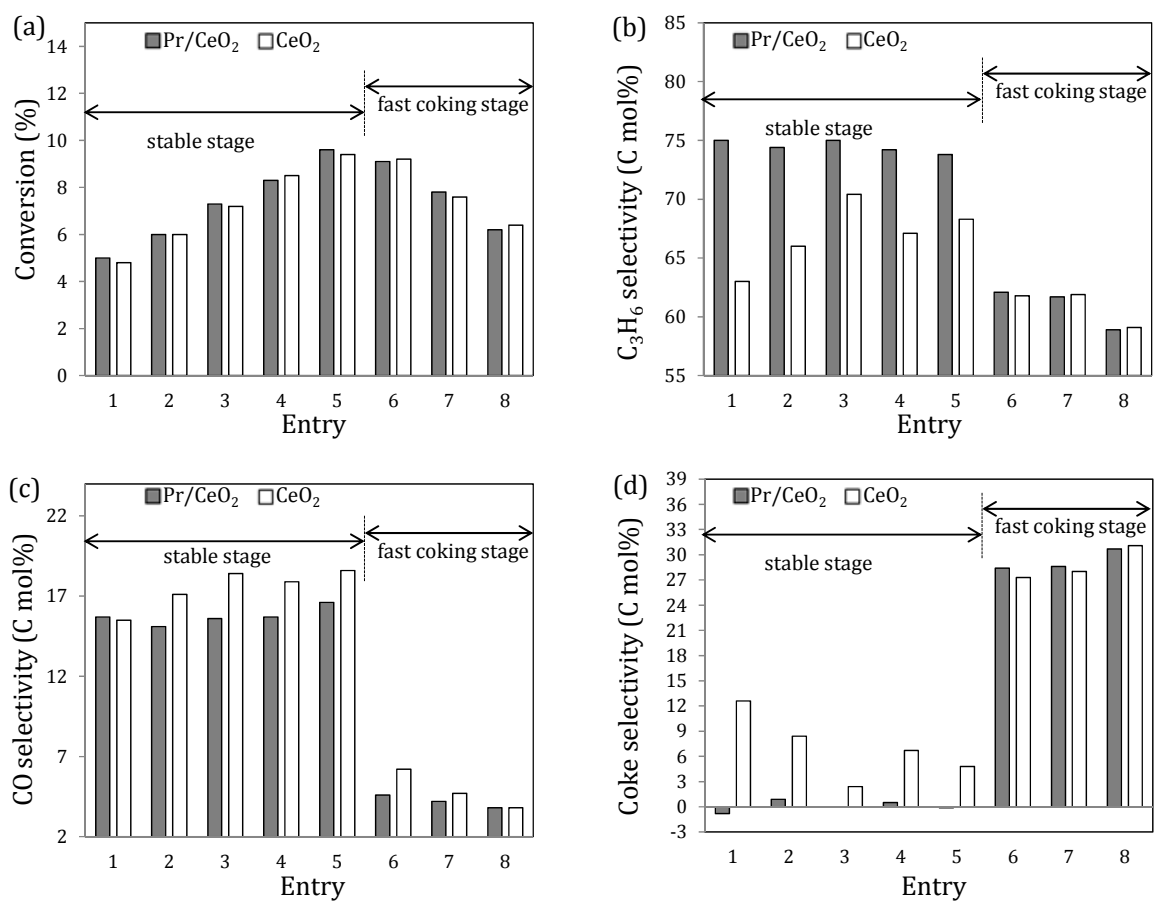

Fig. 9. Conversion (a), propylene selectivity (b), $\mathrm{CO}$ selectivity (c), and coke selectivity (d) for $\mathrm{CeO}_{2}$ and $\mathrm{Pr} / \mathrm{CeO}_{2}$. Coke selectivity is estimated from the carbon loss calculated by the sum of products detected by GC. The negative coke selectivity is due to the precision of the GC quantification (1\% error bar).

selectivity. The propane conversion over a non-metal loaded $\mathrm{Pr} / \mathrm{CeO}_{2}$ catalyst is very appealing with a $75 \%$ selectivity to propylene at a propane conversion around 5\%-10\%. More work is under way to understand and stabilize the oxygen vacancies over $\mathrm{Pr} / \mathrm{CeO}_{2}$.

\section{Conclusions}

In this study, the defects of $\mathrm{CeO}_{2}$ and $\mathrm{Pr} / \mathrm{CeO}_{2}$ are investigated by Raman spectroscopy with different excitation laser lines and an operando UV Raman technique, providing infor- 
mation of the structure and amount of defects, and their evolution at elevated temperatures under the flows of $\mathrm{He}$ and $\mathrm{H}_{2}$. The reducibility of $\mathrm{Pr} / \mathrm{CeO}_{2}$ is investigated by the reactions of hydrogen. The oxygen vacancies of the reduced $\mathrm{PrCeO}_{2-x}$ have the ability to activate the $\mathrm{C}-\mathrm{O}$ bond of $\mathrm{CO}_{2}$ ( $\mathrm{CO}$ as the product) and $\mathrm{C}-\mathrm{H}$ bonds of propane (propylene as the product). The activity and product selectivity relate to its degree of reduction. Pr dopant not only changes the optical properties, the amount and type of defects, and reducibility characteristics, but also changes the selectivities of the propane activation reaction suppressing the formation of byproducts $\mathrm{CO}$ and coke and producing higher propylene selectivity. The degree of reduction of the ceria sample is an important descriptor of the catalytic performance.

\section{Acknowledgments}

We acknowledge Dr. Zhixin Zhang at Dalian Institute of Chemical Physics with the support of catalyst preparation. We thank Benjamin Dennis-Smither and Glenn Sunley from BP International for fruitful discussions.

\section{References}

[1] U. Rodemerck, E. V. Kondratenko, T. Otroshchenko, D. Linke, Chem. Commun., 2016, 52, 12222-12225.

[2] T. Otroshchenko, J. Radnik, M. Schneider, U. Rodemerck, D. Linke, E. V. Kondratenko, Chem Commun., 2016, 52, 8164-8167.

[3] T. Otroshchenko, S. Sokolov, M. Stoyanova, V. A. Kondratenko, U. Rodemerck, D. Linke, E. V. Kondratenko, Angew. Chem. Int. Ed., 2015, 54, 15880-15883.

[4] L. Vivier, D. Duprez, ChemSusChem, 2010, 3, 654-678.

[5] J. Ke, J.-W. Xiao, W. Zhu, H. Liu, R. Si, Y.-W. Zhang, C.-H. Yan, J. Am. Chem. Soc., 2013, 135, 15191-15200.

[6] S. Chen, L. Luo, Z. Jiang, W. Huang, ACS Catal., 2015, 5, 1653-1662.

[7] N. L. Wieder, M. Cargnello, K. Bakhmutsky, T. Montini, P. Fornasiero, R. J. Gorte, J. Phys. Chem. C, 2011, 115, 915-919.
[8] K. Ahn, D. S. Yoo, D.H. Prasad, H.-W. Lee, Y.-C. Chung, J.-H. Lee, Chem. Mater., 2012, 24, 4261-4267.

[9] X. Zhang, Y. Song, F. Guan, Y. Zhou, H. Lv, G. Wang, X. Bao, J. Catal., 2018, 359, 8-16.

[10] Q. Xie, H. Zhang, J. Kang, J. Cheng, Q. Zhang, Y. Wang, ACS Catal., 2018, 8, 4902-4916.

[11] H. Xiong, S. Lin, J. Goetze, P. Pletcher, H. Guo, L. Kovarik, K. Artyushkova, B. M. Weckhuysen, A. K. Datye, Angew. Chem. Int. Ed., 2017, 56, 8986-8991.

[12] Y. Nagai, T. Hirabayashi, K. Dohmae, N. Takagi, T. Minami, H. Shinjoh, S. I. Matsumoto, J. Catal., 2006, 242, 103-109.

[13] S. Zhou, Y. Zhou, J. Shi, Y. Zhang, X. Sheng, Z. Zhang, J. Mater. Sci., 2015, 50, 3984-3993.

[14] A. Thurber, K. M. Reddy, V. Shutthanandan, M. H. Engelhard, C. Wang, J. Hays, A. Punnoose, Phys. Rev. B, 2007, 76, 165206.

[15] B. Vodungbo, Y. Zheng, F. Vidal, D. Demaille, V. H. Etgens, D. H. Mosca, Appl. Phys. Lett., 2007, 90, 062510.

[16] N. S. Ferreira, L. G. Abraçado, M. A. Macêdo, Phys. B, 2012, 407, 3218-3221.

[17] G. Niu, E. Hildebrandt, M. A. Schubert, F. Boscherini, M. H. Zoellner, L. Alff, D. Walczyk, P. Zaumseil, I. Costina, H. Wilkens, T. Schroeder, ACS Appl. Mater. Interfaces, 2014, 6, 17496-17505.

[18] T. Andana, M. Piumetti, S. Bensaid, N. Russo, D. Fino, R. Pirone, Appl. Catal. B, 2016, 197, 125-137.

[19] T. Andana, M. Piumetti, S. Bensaid, N. Russo, D. Fino, R. Pirone, Nanoscale Res. Lett., 2016, 11, 278.

[20] E. Poggio-Fraccari, B. Irigoyen, G. Baronetti, F. Mariño, Appl. Catal. A, 2014, 485, 123-132.

[21] A. Davó-Quiñonero, J. González-Mira, D. Lozano-Castelló, A. Bueno-López, Catal. Lett., 2018, 148, 258-266.

[22] Z. Zhang, Y. Wang, J. Lu, J. Zhang, M. Li, X. Liu, F. Wang, ACS Catal., 2018, 8, 2635-2644.

[23] Z. Zhang, Y. Wang, J. Lu, C. Zhang, M. Wang, M. Li, X. Liu, F. Wang, ACS Catal., 2016, 6, 8248-8254.

[24] L. Li, F. Chen, J.-Q. Lu, M.-F. Luo, J. Phys. Chem. A, 2011, 115, 7972-7977.

[25] I. Tankov, K. Arishtirova, J. M. C. Bueno, S. Damyanova, Appl. Catal. $A$, 2014, 474, 135-148.

[26] B. Matovic, S. Boskovic, M. Logar, M. Radovic, Z. Dohcevic-Mitrovic,

\section{Graphical Abstract}

Chin. J. Catal., 2019, 40: 1800-1809 doi: S1872-2067(19)63369-3

\section{Activation of small molecules over praseodymium-doped ceria}

Meiling Guo, Xuebin Liu, Angelo Amorelli *

BP (China) Dalian Office, China; BP International, United Kingdom

The praseodymium-doped ceria material in the absence of hydrogenation/dehydrogenation metals can selectively activate $\mathrm{C}-\mathrm{H}$ bond of propane, giving a propylene selectivity of ca. $75 \%$ at a propane conversion of $5 \%$ to $10 \%$.

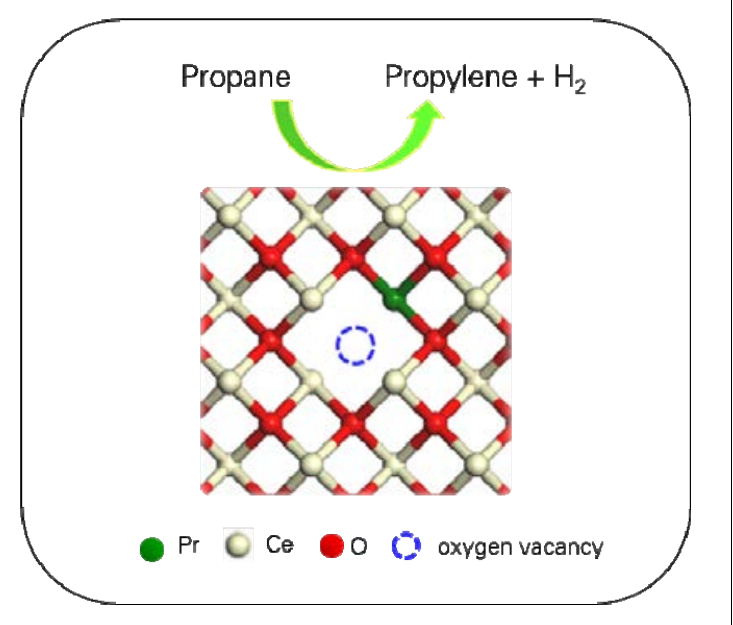


Z. V. Popovic, F. Aldinger, J. Alloys Compd., 2010, 505, 235-238.

[27] M. Guo, J. Lu, Y. Wu, Y. Wang, M. Luo, Langmuir, 2011, 27, 3872-3877.

[28] F. Fan, Q. Xu, H. Xia, K. Sun, Z. Feng, C. Li, Chin. J. Catal., 2009, 30, 717-739.

[29] S. Bensaid, M. Piumetti, C. Novara, F. Giorgis, A. Chiodoni, N. Russo, D. Fino, Nanoscale Res. Lett., 2016, 11, 494.
[30] Z. Wu, M. Li, J. Howe, H. M. Meyer, S. H. Overbury, Langmuir, 2010, 26, 16595-16606.

[31] V. K. Tripathi, R. Nagarajan, Solid State Sci., 2018, 84, 1-7.

[32] S. M. Schimming, G. S. Foo, O. D. LaMont, A. K. Rogers, M. M. Yung, A. D. D’Amico, C. Sievers, J. Catal., 2015, 329, 335-347.

[33] S. Pradhan, D. C. Upham, H. Metiu, E. W. McFarland, Catal. Sci. Technol, 2016, 6, 5483-5493.

\title{
镨掺杂氧化铈材料在小分子活化中的应用 \\ 郭美玲a, 刘雪斌, Amorelli Angelo b,* \\ 碧辟能源创新实验室, 碧辟(中国)大连办公室, 辽宁大连 116023, 中国 \\ b英国石油公司，森伯里，英国
}

\begin{abstract}
摘要: 氧化铈材料具有独特的氧化还原特性, 常作为优异载体或助剂广泛应用于多种催化反应. 未担载常规活性金属的氧 化铈作为助剂在低碳烷烃的活化研究中非常有限. 我们前期研究发现, 镨掺杂的氧化铈 $\left(\mathrm{Pr} / \mathrm{CeO}_{2}\right)$ 可高效催化异丁烯与甲 醛水溶液的Prins缩合-水解反应. 本文在此基础上研究了 $\mathrm{Pr} / \mathrm{CeO}_{2}$ 材料对 $\mathrm{CO}_{2}$ 和丙烷等小分子的活化, 并将反应活性及选择 性与材料的还原度(氧空位浓度)相关联. 结果表明, 与未掺杂的氧化铈材料相比, $\mathrm{Pr} / \mathrm{CeO}_{2}$ 可显著提高材料的表面还原度. 通过进一步调变氢气预还原温度得到了一系列具有不同还原度的材料, 它们展示出对 $\mathrm{CO}_{2}(\mathrm{C}-\mathrm{O}$ 键)不同的活化性能. 不同 还原度的 $\mathrm{Pr} / \mathrm{CeO}_{2}$ 催化丙烷脱氢的反应活性及产物的选择性与其还原度有关, 氧空位是丙烷脱氢的活性中心, 可选择性地 活化丙烷中的 $\mathrm{C}-\mathrm{H}$ 键. $\mathrm{Pr} / \mathrm{CeO}_{2}$ 材料在 $5 \%-10 \%$ 丙烷转化率条件下可获得 $75 \%$ 的丙烯选择性.
\end{abstract}

关键词: 氧化铈; 镨掺杂; 氧空位; 还原度; 丙烷脱氢

收稿日期: 2019-01-29. 接受日期: 2019-04-04. 出版日期: 2019-11-05.

*通讯联系人. 电子信箱: angelo.amorelli@bp.com

本文的电子版全文由Elsevier出版社在ScienceDirect上出版(http://www.sciencedirect.com/science/journal/18722067). 